\title{
De medische opleiding een continuüm!?
}

De medische opleiding is een lange opleiding. Een student volgt eerst minimaal zes jaar de opleiding tot basisarts en daarna nog een van de vele vervolgopleidingen. Door de lengte van dit traject en het feit dat er tussen artsexamen en begin van de vervolgopleiding vaak nog een periode zit, zijn beginnende specialisten over het algemeen ouder dan dertig jaar. Onlangs is gesteld dat de beginnende specialist te oud is. Vervolgens zijn discussies begonnen over verkorting van de vervolgopleiding en/of de basisopleiding. Ook is voorgesteld om tijdwinst te behalen door differentiatie in de basisopleiding in te voeren. Hiermee wordt bedoeld dat er binnen de basisopleiding al keuzes gemaakt worden voor bijvoorbeeld snijdende of nietsnijdende vakken. Het is heel goed dat deze discussies plaatsvinden. Als het beter en korter kan, heeft iedereen daar baat bij.

In deze discussies moet mijns inziens meer aandacht besteed worden aan de opleiding als continuüm. Een betere afstemming tussen basisartsopleiding en vervolgopleidingen kan veel tijd- en leerwinst opleveren. Daarnaast denk ik dat zowel de basisartsopleiding als de vervolgopleidingen ingekort kunnen worden als de na- en bijscholing ook als opleiding wordt ingevuld. In het traject na de vervolgopleiding zou dan structuur moeten komen met een leerplan voor een bepaalde groep dokters en mijns inziens ook voor elke individuele dokter.
Wat een administratie, wat een gedoe en wie moet dat allemaal betalen! Dit zijn vragen die ik me kan voorstellen. Of er echt financiële belemmeringen zijn, vraag ik me af. Er gaat nu ook al heel veel geld om in na- en bijscholing en opleiding. Het lijkt me mogelijk om dat geld beter te besteden en daarmee opleidingswinst te behalen.

Het is wel wat meer gedoe, dat klopt. Maar het hoeft niet allemaal centraal geregeld te worden en dus heel veel extra administratie op te leveren. Dokters kunnen zelf ook een grote rol spelen. Als ze in de opleiding goed geleerd hebben om zichzelf te beoordelen, kunnen ze zelf hun leerplan opstellen. Als hulpmiddel kan ik me ook voorstellen dat er met een zekere regelmaat diagnostische toetsen worden afgenomen. De uitslag hiervan is bedoeld als feedback en geeft zonodig aanwijzingen voor het bijstellen van het leerplan.

$\mathrm{Er}$ is ook veel tijd- en leerwinst te behalen door in de basisartsopleidingen en vervolgopleidingen het leren van de student en de arts centraal te stellen. Oppervlakkig gezien is dat nogal logisch en iedereen zal het er wel mee eens zijn. Maar als je vanuit deze insteek naar de huidige opleidingen kijkt, dan kan er heel wat uit.

Samenvattend, ben ik van mening dat de medische opleiding nu absoluut geen continuüm is. Als we van het medisch opleidingstraject een echt continuüm maken, kan het ook wel korter.

\section{A.J.J.A. Scherpbier}

